\title{
Marlena Rycombel
}

https://orcid.org/0000-0003-4971-7566

Uniwersytet Warszawski

e-mail: m.rycombel@uw.edu.pl

\section{KAPUŚCIŃSKI NON-FICTION JAKO BIOGRAFIA POLITYCZNA. LEWICOWOŚĆ KAPUŚCIŃSKIEGO W KONTEKŚCIE PARALIŻU DYSKURSU O PRL-U}

Kapuściński non-fiction as a political biography. The leftism of Kapuściński in the context of the discourse on Polish People's Republic

\begin{abstract}
In the article, the author is surveying the scientific discourse on political threads embraced in the Kapuściński non-fiction biography written by Artur Domosławski. This discourse spectacularly reveals the wider problem with the discourse on the Polish People's Republic. There will be indicated how presuppositions concerning Ryszard's Kapuściński leftism (valorized the leftism positively or negatively) position the interpretation of the book Kapuściński non-fiction. Various typologies of the discourse on PRL will be enumerated and the problem of whether the biography written by Artur Domosławski eludes the classical narration on real socialism will be discussed.
\end{abstract}

Keywords: Kapuściński non-fiction, discourse of communism, the Left, PRL, Ryszard Kapuściński

Temperaturę dyskusji nad Kapuściński non-fiction ${ }^{1}$ (KNF) porównuje się do tej, która odbyła się po wydaniu Sąsiadów Jana Tomasza Grossa². To zestawienie - wydawałoby się, że nieoczywiste - opiera się na przekonaniu, że obydwie publikacje sprzeciwiły się obowiązującym narracjom obecnym w polskiej debacie publicznej oraz wywołały żarliwe spory. Podczas gdy Sąsiedzi zawierają nieopowiedzianą historię stosunków polsko-żydowskich, biografia KNF dobitnie opisuje nieopowiedzianą

\footnotetext{
A. Domosławski, Kapuściński non-fiction, Wydawnictwo Świat Książki, Warszawa 2010.

Zob. A. Kowalska, Kapuściński z PRL-u [w:] M. Hopfinger, Z. Ziątek, T. Żukowski (red.), Literatura bez fikcji. Między sztuka a codziennościa. W stronę nowej syntezy (3), Wydawnictwo IBL PAN, Warszawa 2018, s. 189; R. Szymanowski, Kapuściński non-fiction - próba analizy debaty publicznej, „Refleksje. Pismo Naukowe Studentów i Doktorantów WniPD UAM” 2012, nr 6, s. 162.
} 
postawę inteligenta $\mathrm{w}$ dobie PRL-u - postawę trudno mieszczącą się w popularnych dychotomiach. Książka napisana przez dziennikarza Artura Domosławskiego (prywatnie ucznia i przyjaciela Ryszarda Kapuścińskiego) sprowokowała dyskusje nie tylko na temat kategorii literackości w reportażu i granic jej wykorzystywania, warsztatu reportera czy etycznych uprawnień biografisty, lecz przede wszystkim wyraźnie sproblematyzowała komunistyczne poglądy Kapuścińskiego, kreśląc obraz wielkiego pisarza związanego z PZPR-em. Konflikt urósł do rangi ogólnonarodowego: biografia poruszyła dziennikarzy, czytelników, filologów, historyków - zarówno ludzi kultury, nauki, jak i polityki. W artykule przedstawię dyskurs naukowy wokół wątków politycznych zawartych w KNF, który stanowi spektakularną metonimię szerszego dyskursu o Polsce Ludowej; innymi słowy wskażę, jak presupozycje dotyczące lewicowości Kapuścińskiego (waloryzujące ją negatywnie bądź pozytywnie) ustawiają sposób interpretacji dzieła KNF. Przede wszystkim skupię się na tekstach Anny Kowalskiej ${ }^{3}$ oraz Adriana Stachowskiego ${ }^{4}$, ale również - Grzegorza Wołowca ${ }^{5}$ i Rafała Szymanowskiego ${ }^{6}$.

Anna Kowalska, autorka publikacji Kapuściński w PRL, uznaje, że biografia KNF wywołała skandal przede wszystkim dlatego, iż poruszyła wątek wiary Kapuścińskiego w ZSRR. Jak to możliwe, skoro pionierska biografia Kapuścińskiego Beaty Nowak i Zygmunta Ziątka ${ }^{7}$ nie odżegnywała się od trudnych tematów, zawierała informacje o socjalistycznych upodobaniach reportażysty czy niemal trzydziestoletnim członkostwie Kapuścińskiego w PZPR? Biorąc również pod uwagę, że skandal KNF nie był pierwszą aferą lustracyjną?

Novum KNF - w stosunku do wcześniejszych afer dotyczących weryfikacji teczek wywołanych przez prawicę - polega jednak na tym, że wiwisekcję lewicowości najsłynniejszego polskiego reportażysty przeprowadza znany lewicowy dziennikarz, który oświadcza, że nie chce Kapuścińskiego oceniać. Wręcz przeciwnie - jego celem jest wielowymiarowe pokazanie uwikłań reportera, rozumienie jego sytuacji i tym samym podjęcie refleksji nad typowym życiorysem inteligenta czasów PRL-u. Kwestią dyskusyjną pozostaje pytanie, czy deklaracja Domosławskiego była uczciwa i czy rzeczywiście KNF momentami nie przybiera kształtu oskarżenia Kapuścińskiego?

Przyczyną silnego podziału sporu wokół KNF jest niejednoznaczność ukryta w samej biografii. Stąd słynna konstatacja Wojciecha Tochmana: „Mam wrażenie jednak, że każda z osób, która dotychczas zabierała w mediach głos, czytała trochę

Ibidem, op. cit.

4 A. Stachowski, Spór o Kapuścińskiego, Wydział Dziennikarstwa i Nauk Politycznych, Warszawa 2015.

5 G. Wołowiec, O Domosławskim i jego krytykach, „,Teksty Drugie” 2011, nr 1/2, s. 279-287.

$6 \quad$ R. Szymanowski, Kapuściński non-fiction ..., op. cit.

7 B. Nowacka, Z. Ziątek, Ryszard Kapuściński. Biografia pisarza, Wydawnictwo Znak, Kraków 2008, s. 233-237. 
inną książkę, książkę o czym innym". Dlaczego każdy czytał inną książkę? Cechą charakterystyczną analizowanej publikacji stanowi bowiem jej swoiste rozdwojenie - z jednej strony Domosławski deklaruje, że chce oddać hołd Kapuścińskiemu, co wielokrotnie zaznacza i, jak sądzę, jego zamiar jest szczery. Z drugiej - podczas czytania KNF nie sposób nie wyczuć fałszywej melodii, która jest wyrazem trudności radzenia sobie autora Goraczki latynoamerykańskiej z dwoma rodzajami tabu - osobistym i publicznym. Fałszywa nuta najpełniej wyraża się w języku i konstrukcji narracyjnej KNF, w sposobie stawiania pytań i odpowiedziach na nie. Pierwsze tabu odnosi się do pokoleniowej konfrontacji z mistrzem, która przywodzi na myśl mityczne zabójstwo Lajosa przez Edypa. To próba odżegnania się od stylu pracy głośnego autorytetu i stworzenia reguł nowej poetyki reportażu. Drugie tabu dotyczy sposobu (nie)mówienia o różnych obliczach lewicowości w czasie PRL-u. Domosławski szuka nowego języka, ale sam potyka się o aporię dyskursu; wpada w pułapkę, od której sam stara się uciec.

\section{Tryb prokuratorski i adwokacki}

Przyczyny dwuznaczności w postawie Domosławskiego są w głównej mierze związane z paraliżem dyskursu o PRL-u, o którym Anna Kowalska pisze w tekście Wokót dyskursu o $P R L^{9}$. Tworzy w nim poręczne kategorie określające podzieloną dyskusję o minionym ustroju. Według autorki o PRL-u można mówić tylko w trybie oskarżenia bądź obrony, innymi słowy - dyskurs rozpołowił się na tryb prokuratorski i adwokacki ${ }^{10}$. Istnieje wspólny mianownik tych dyskursywnych postaw - założenie, że system PRL był esencjonalnie zbrodniczy, a tym samym sympatyków Polski Ludowej należy poddawać rytualnej krytyce. Autorka wskazuje, że dominujący opis PRL-u odnosi się do wyobrażenia o uciskanym społeczeństwie, które zostało zaatakowane przez zewnętrzny system. Badaczka jest zaskoczona brakiem dynamizmu tej narracji, stąd zachęca do badań nad PRL-em, które odnosiłyby się do kategorii praktyk społecznych i codzienności. Kowalska przekonuje, że ukazałyby one wielość prawd o Polsce Ludowej.

Domosławski w KNF utknął pomiędzy trybem oskarżenia a obrony. Fakt, że ktokolwiek zaczął w debacie publicznej mieszać owe tryby, stanowi innowację, która jest jedną z przyczyn skandaliczności KNF. Stąd też wynika drastycznie różny odbiór tej książki. Część czytelników przeczytała, że Domosławski jednoznacznie

8 Zapis debaty o książce Artura Domosławskiego, którą 17 marca 2010 roku w Warszawie w Muzeum Sztuki Nowoczesnej zorganizował Instytut Reportażu, zob. http://wyborcza.pl/magazyn/1,124059,7706711,Kapuscinski_bez_znieczulenia_Kazdy_czytal_inna_ksiazke.html (dostęp: 4.01.2021).

9 A. Kowalska, Wokół dyskursu o PRL [w:] M. Hopfinger, Z. Ziątek, T. Żukowski (red.), Debaty po roku 1989. Literatura $w$ procesach komunikacji. W stronę nowej syntezy (2), Wydawnictwo IBL PAN, Warszawa 2017.

$10 \quad$ Ibidem, s. 67. 
krytykuje związki Kapuścińskiego z socjalizmem, podczas gdy inni zachwycili się, że ktoś pisze o wielkim autorytecie inaczej niż na kolanach, jeszcze inni - zdecydowana mniejszość, przedstawiciele lewicy - przyjęli z radością książkę, która opisuje sylwetkę ideowca uwikłanego w autorytaryzm z powodu swoich szczerych przekonań. Stąd słynne zdanie Wojciecha Tochmana: „Każdy przeczytał inną książkę”. Sprzeczne reakcje wynikają bowiem z monolitu opowieści o polskim socjalizmie i nieumiejętności czytelników zmierzenia się z dwuznacznością KNF, która ostatecznie doprowadziła do interpretacyjnej jednoznaczności obecnej w opowieściach poszczególnych obozów - każdy zaprzągł Domosławskiego do dyskursu, który mu pasował. Powtarzające się zatem twierdzenie, że spór o KNF wyszedł poza opozycję lewica-prawica, ma swe źródło w ambiwalencji języka KNF.

Domosławski jednocześnie potępia Kapuścińskiego, ale i próbuje go rozumieć. Zaznaczam jednak, że tryb prokuratorski przeważył na poziomie języka, podczas gdy na poziomie deklaracji samego autora - tryb adwokacki. Interesującą ambiwalencję KNF zredukowano do frakcyjnych potyczek. Anna Kowalska, Adrian Stachowski oraz Rafał Szymanowski i Grzegorz Wołowiec błyskotliwie rozpoznali, że fenomen KNF polega między innymi na jego polityczności i walce z paraliżem dyskursu PRL-u, niemniej nie zauważyli sprzeczności, z którymi boryka się sam Domosławski.

\section{Kapuścińskiego wiara w ruch odnowy socjalizmu}

Adrian Stachowski słusznie twierdzi:

Twórczość Kapuścińskiego przebadano do tej pory ze wszystkich stron: krytyczno-literackiej, teoretyczno-dziennikarskiej, antropologicznej, kulturoznawczej i semiotycznej. Dlatego trudno zgodzić się z Domosławskim, gdy twierdzi, że Kapuścińskiego „nie przemyślano”. Jednocześnie rzeczywiście nikt nie wpisał jego dzieł w kontekst polityczny (...). Prawdą jest, że w licznej grupie badaczy twórczości Kapuścińskiego przeważają literaturoznawcy, medioznawcy i antropolodzy, a brakuje wśród nich reprezentantów nauk politycznych i historyków. Inną kwestią jest prymat, jaki zdaje się przypisywać Domosławski tej „politycznej” perspektywie badania życia i twórczości autora Cesarza ${ }^{11}$.

Badacz pokazuje jeszcze, że Kazimierz Wolny-Zmorzyński, jeden z najważniejszych znawców twórczości Kapuścińskiego, wprawdzie napisał książkę Wobec świata i mediów: Ryszarda Kapuścińskiego dylematy dziennikarskie, literackie i spoteczno-polityczne, ale polityczność sprowadza on do filozofii polityki i socjologii władzy, nie nadając jej konkretnego kształtu ${ }^{12}$. Ponadto w pisarstwie na temat Kapuścińskiego dominuje przeświadczenie, że porzucił on swoje zaufanie do systemu komunistycznego w czasie odwilży, podczas gdy Domosławski w KNF zaznacza

11 A. Stachowski, Spór o Kapuścińskiego, op. cit., s. 14.

12 Ibidem, s. 11. 
bardzo wyraźnie: Kapuściński był wierzącym socjalistą, który również po transformacji ustrojowej krytycznie podchodził do kapitalizmu. Stachowski wskazuje, że Beata Nowacka i Zygmunt Ziątek w biografii pisarskiej Kapuścińskiego przyjmują zadziwiającą postawę wobec lewicowości swojego bohatera: choć nie omijają wątków kontrowersyjnych, unikają języka konkretu. W ten sposób autor Cesarza staje się kibicem budowania socjalizmu, a nie jego współtwórcą, umniejszają oni znaczenie publikacji Kapuścińskiego w „Sztandarze Młodych” w latach 1951-1955, choć te miały miejsce kilka razy do roku, a krytyczną wobec władzy perspektywę zawartą w jego tekstach uważają za silny wyraz niezgody na system, a nie za dowód wiary w ruch odnowy socjalizmu, co tak mocno podkreślił Domosławski ${ }^{13}$. Stachowski zwraca też uwagę, że badacze pobłażali stalinizmowi Kapuścińskiego, uważając go za błędy młodości ${ }^{14}$. W wyważony sposób o lewicowości Kapuścińskiego pisze w swojej autobiografii jego przyjaciel Jerzy Nowak, kiedy wspomina wspólny pobyt w Dar es-Salaam w 1961 roku:

W czasie niemal codziennych spacerów nad brzegiem oceanu nie ukrywał coraz bardziej krytycznego stosunku do rozwoju sytuacji w Polsce i kierunku, w jakim zmierzał „realny” socjalizm. Mimo swego oddania idealistycznie pojmowanej „sprawie socjalizmu” potrafił dostrzec, że kraj nie modernizuje się wystarczająco, ideały wolności i demokracji są naruszane, represje się utrzymują, zależność od ZSRR jest podstawą ustroju, a partia jest coraz bardziej nastawiona po prostu na trwanie przy władzy. Nie obalało to jednak jego wiary, że socjalizm ma jeszcze potencjał i może być gruntownie zreformowany ${ }^{15}$.

Autobiografia Nowaka powstała cztery lata po biografii autorstwa Domosławskiego. Dyplomata mocno podkreśla w niej romantyczne podejście Kapuścińskiego do socjalizmu, nie koniunkturalne. Domosławski zwraca uwagę na konformistyczno-ideowy wymiar socjalizmu Kapuścińskiego.

Jedną z największych zalet książki Domosławskiego stanowi obalenie tezy, jak gdyby Kapuściński po odwilży stał się jednoznacznym krytykiem PRL-u - autor Goraczki latynoamerykańskiej przekonuje, że Kapuściński nigdy nie przestał być lewicowcem i był nie tyle oskarżycielem rzeczywistości politycznej PRL-u, ile zwolennikiem ruchu odnowy socjalizmu. Jego krytyka zatem była wyrazem wiary w reformę realnego socjalizmu. Z drugiej - autor KNF jest mało uwrażliwiony na niewątpliwie antysystemowy wymiar twórczości reportażysty, na szczodrze używaną przez niego mową ezopową. Być może to czas - właśnie dzięki Domosławskiemu - by przeczytać dzieła Kapuścińskiego nie tylko od strony mowy ezopowej, ale również zawartych w nich wątków propagandowych bądź jego politycznej (a nie abstrakcyjnej) wiary w rewolucję? Dzięki temu uzyskamy bardziej skomplikowany obraz jego pisarstwa oraz realiów, w których żył. W tej perspektywie czytanie za pomocą klucza biograficznego Imperium, dzieła pisanego już po pierestrojce i rozpadzie

13 Ibidem, s. 29-30.

14 Ibidem, s. 31.

15 J.M. Nowak, Dyplomata. Na salonach i w politycznej kuchni, Bellona, Warszawa 2014, s. 190. 
Rosji radzieckiej, stanowi dzisiaj być może najciekawszy sposób lektury tej książki, odsłaniający sprzeczności myślowe i moralne wielkich postaci XX wieku. Wówczas orientalne opisy Rosji Kapuścińskiego ukazują swoje ukryte oblicze: niejednoznaczne, zawikłane, prowokujące również do pytań o ograniczenia teorii postkolonialnej. W Imperium Kapuściński miał szansę stworzyć nieocenzurowaną opowieść o socjalizmie. Ale co równie ważne - język tego dzieła został ocenzurowany przez dyskurs pokomunistycznej Polski.

Kapuściński był zwolennikiem rewolucji marksistowskiej - zdecydowanie bardziej utożsamiał się z komunizmem Marksa niż z czerwoną burżuazją, a układy z dygnitarzami pozwoliły mu opisać 27 przewrotów; przewrotów dokonywanych pod czujnym okiem ZSRR. Najciekawszym przykładem jest rewolucja w Angoli w 1975 roku. O wpływy w niepodległej Angoli walczyło kilka stronnictw, które były wspierane przez różne państwa - Kapuściński dołączył do MPLA - Ludowego Ruchu Wyzwolenia Angoli wspieranego przez ZSRR i Kubę. Nie tylko dlatego, że był wówczas korespondentem PAP zależnym od Polski Ludowej. Kapuściński istotnie wierzył w rewolucję.

Czy Kapuściński kiedykolwiek zmienia swój stosunek do PRL-u? Po wydarzeniach sierpniowych w 1980 roku wstępuje do Solidarności i jednocześnie angażuje się w działania na rzecz odnowy partii PZPR w kierunku demokratycznym ${ }^{16}$.

\section{Język perswazji KNF}

Stachowski zwraca uwagę, że wielu zagranicznych recenzentów odczytało KNF głównie jako dowód kłamliwości reportaży Kapuścińskiego oraz świadectwo jego wątpliwej postawy etycznej jako współpracownika wywiadu i członka PZPR, co niejednokrotnie doprowadziło do potępienia jego osoby i twórczości. Stachowski twierdzi stanowczo, że to błąd niekompetentnych dziennikarzy, którzy nie przeczytali biografii uważnie, oraz ich nieznajomości realiów realnego socjalizmu ${ }^{17}$. Usprawiedliwia Domosławskiego, twierdząc, że jego książka nie ma charakteru demaskatorskiego. Badacz nie zwraca tym samym uwagi na siłę retoryczną KNF, polegającą na jej emocjonalnym języku i perswazyjnym stawianiu nieprzychylnych hipotez czy wykorzystaniu zabiegów i narracji typowej dla reportażu śledczego. Badacz nie zauważa więc ambiwalencji biografii i nie dostrzega dwuznacznej intencji autorskiej, zrzucając odpowiedzialność za negatywny odbiór postaci Kapuścińskiego w KNF na zagranicznego czytelnika.

Anna Kowalska w tekście Kapuściński w PRL przekonuje, że Domosławski stara się odzyskać cesarza reportażu dla lewicy. Moim zdaniem bardziej atakuje on Kapuścińskiego z perspektywy lewicy, niż go dla niej odzyskuje, choć niewątpliwie deklaruje chęć zrozumienia mistrza oraz próbuje odkryć mechanizmy jego postawy

16 B. Nowacka, Z. Ziątek, Ryszard Kapuściński..., op. cit., s. 233-237.

17 Ibidem, s. 126-127. 
będącej mieszaniną buntu i konformizmu. Dziennikarz zwraca uwagę na rozczarowanie Kapuścińskiego kształtem transformacji ustrojowej, co zdecydowanie przybliża cesarza reportażu do współczesnej lewicy. Z drugiej - wskazuje na kolonialne elementy myślenia obecne w jego twórczości, zarzuca mu, że nie wythumaczył się po 1989 roku ze swoich związków z socjalizmem, krytykuje wyidealizowane opowieści o Pińsku, miejscowości urodzenia Kapuścińskiego, ignorujące antysemickie problemy.

Kowalska, pisząc o tym, że Domosławski bez uprzedzeń podchodzi do lewicowości Kapuścińskiego, nie zwraca uwagi na emocjonalny język KNF, który obnaża ambiwalentną postawę w stosunku do mistrza - pełną podziwu, zazdrości i wielkiej złości zarazem. Domosławski posługuje się bowiem językiem lustracji! Jest w niego uwikłany - tak samo jak debata publiczna. Kowalska mówi wprost: cel Domosławskiego jest demaskatorski, ale jednocześnie życzliwy. Ale czy demaskacja może być życzliwa w warunkach językowego status quo, w którym jedynym repertuarem retorycznym jest tryb adwokacki bądź prokuratorski?

W KNF Domosławski wielokrotnie obiecuje, że nie tyle chce osądzać Kapuścińskiego, ile wejść w głąb jego motywacji oraz zrozumieć jego losy i wybory. Nieraz podkreśla, że ukąszenie heglowskie dla samego Kapuścińskiego nie było problemem wielkiego kalibru i nie rozpatrywał go z perspektywy absolutnego zła. Dla Kapuścińskiego współpraca z PZPR-em nie stanowiła oczywistej ideowej porażki, natomiast dla pokolenia Domosławskiego ta kwestia już częściej maluje się w biało-czarnych barwach.

\section{Kło jest przegranym - Kapuściński czy Domosławski?}

Retoryka publicystycznego (i części naukowego) sporu wokół KNF skupiła się wokół słownictwa z pola tematycznego rozprawy sądowej: niektórzy oskarżali Domosławskiego, jednocześnie broniąc Kapuścińskiego, inni - na odwrót.

Kowalska na samym początku artykułu deklaruje, że nie zamierza ani atakować, ani bronić którejkolwiek ze stron sporu. Założenie to okazuje się jednak ideałem niemożliwym w realizacji, a jej tekst to w dużej mierze obrona Domosławskiego. Artykuł nie stanowi jednak ataku na Kapuścińskiego, ponieważ autorka w zasadzie nie komentuje jego sprawy; skupia się na tym, co Domosławski wniósł do opowieści o Kapuścińskim. Powstało bardzo mało wyważonych opinii, które pozwoliłyby docenić i skrytykować zarówno Domosławskiego, jak i Kapuścińskiego. Sympatycy Domosławskiego przekonani są, że w walce o prawdę przegrywają z obozem Kapuścińskiego, podczas gdy sympatycy Kapuścińskiego czują, że są ofiarą hermeneutycznej metody Domosławskiego.

$\mathrm{Na}$ łamach trzytomowej serii $W$ stronę nowej syntezy, wydanej przez Instytut Badań Literackich, na temat tych dwóch reporterów, oprócz Anny Kowalskiej, 
wypowiada się również Zygmunt Ziątek ${ }^{18}$ (który wspólnie z Beatą Nowacką napisał pierwszą biografię Ryszarda Kapuścińskiego ${ }^{19}$ ). Kowalska i Ziątek to interesujący dwugłos głosów przeciwnych. Kowalska pisze Kapuściński z PRL-u przekonana, że biografia KNF została oceniona nieuczciwie, więc razem z Domosławskim twierdzi, że dyskusja wokół książki nie została należycie wykorzystana, szczególnie w kwestii dotyczącej literackości reportażu. Autorka twierdzi, że obóz Domosławskiego jest na przegranej pozycji:

Paradoksalnie również jego [Domosławskiego - przyp. M.R.] nie potraktowano poważnie. Ważne „sprawy”, przez które opisał swojego bohatera, nie spotkały się ze zrozumieniem w głównym nurcie polskiego dyskursu. W centrum znalazły się oskarżenia pod adresem biografa, które w ogromnym stopniu zdominowały recepcję książki. Ich analiza ujawnia wyraźnie to, co ich autorzy przypisywali Domosławskiemu - „hermeneutykę podejrzeń”, każącą podejrzewać go o najniższe pobudki ${ }^{20}$.

Z kolei Ziątek twierdzi zupełnie odwrotnie - to obóz Kapuścińskiego przegrywa! W dyskusji wokół KNF retoryka wyścigu, w której ważniejsze okazuje się to, kto przegrywa, a nie kto wygrywa, stanowi zdumiewająco ważny element. Ziątek posługuje się wręcz narracją ofiary i z gorzkim żalem mówi o konflikcie międzypokoleniowym: nowa generacja dziennikarzy i czytelników reprezentowana przez Domosławskiego nie rozumie literackości używanej przez Kapuścińskiego, którą pierwszy biografista Kapuścińskiego ceni niezwykle wysoko:

Wygląda na to, że dwuwarstwowy znaczeniowo model reportażu literackiego, o który walczył Kish i który z przekonaniem realizowali jeszcze Krall, Kąkolewski czy Kapuściński, schodzi ze sceny, a wraz z tym zmniejsza się zdolność rozumienia jego historycznych uzasadnień. Wydaje się w każdym razie, że dla reportażystów następnych pokoleń model ten - rozumiany czy nie - jest już trudny do kontynuacji. Opór przeciwko niemu przybrał przede wszystkim postać rozliczeń z reportażem Kapuścińskiego; autor Cesarza jako niekwestionowana przez wiele lat ikona gatunku bardzo dobrze się do tego nadawał ${ }^{21}$.

Nie wiemy, kto rzeczywiście w zarysowanym konflikcie wygrywa - adwokaci Kapuścińskiego czy Domosławskiego. Nie posiadamy danych ilościowych pokazujących skalę i przebieg dyskusji. W tej perspektywie widać, jak pomocne mogłoby się okazać socjologiczne badania nad recepcją sporu, które zebrałyby i policzyły głosy dyskutantów oraz opisały ich rodzaj (wzory środowiskowego poparcia dla stron, możliwe podziały polityczne i pokoleniowe). Ważnym krokiem w drobiazgowym opisie odbioru KNF stanowi książka Adriana Stachowskiego Spór o Kapuścińskiego

18 Z. Ziątek, Reportaż - fotografia - nowe kryteria wiarygodności [w:] M. Hopfinger, Z. Ziątek, T. Żukowski (red.), Między sztuka a codziennością. W stronę nowej syntezy (1), Wydawnictwo IBL PAN, Warszawa 2016.

19 B. Nowacka, Z. Ziątek, Ryszard Kapuściński..., op. cit.

20 A. Kowalska, Kapuściński z PRL-u, op. cit., s. 236.

21 Z. Ziątek, Reportaż-fotografia..., op. cit., s. 87. 
- autor wykorzystuje nie tyle narzędzia socjologii literatury, ile analizę dyskursu prasowego.

W dyskursie naukowym można zauważyć następujący (niemal idealnie symetryczny) rozkład sił: zwolenników biografii jest pięciu (Szymanowski ${ }^{22}$, Wołowiec ${ }^{23}$, Kowalska, Zajas ${ }^{24}$, Stachowski), zdecydowanych przeciwników czterech (Glensk ${ }^{25}$, Ziątek i Nowacka ${ }^{26}$, Sokołowski ${ }^{27}$ ). Głos Stachowskiego należy do najbardziej wyważonych; pochwala on polityczność KNF, ale mocno też krytykuje pewne aspekty biografii.

Z kolei Grzegorz Wołowiec pisze, że w dyskursie publicystycznym przeważa strona przeciwników Domosławskiego; autor powołuje się jednak nie na skrupulatnie sprawdzone dane, ale na swoje wrażenie lekturowe. Wołowiec podkreśla, że jego opinia nie jest odosobniona oraz że sam Domosławski twierdzi, że przeważają głosy jemu nieprzychylne (jak gdyby autor KNF był autorytetem w tej sprawie):

W niezwykle obfitej recepcji zdecydowanie dominuje ton krytycznej polemiki, a często nawet całkowitego, wręcz gwałtownego odrzucenia. Ocenę tę formułuję na podstawie lektury około stu rożnogatunkowych wypowiedzi poświęconych napisanej przez Domosławskiego biografii (...) oraz setek krótkich zazwyczaj opinii, wyrażanych na rozmaitych portalach i stronach internetowych. Moja o pini a [podkr. - M.R.] o niekorzystnym dla Domosławskiego przebiegu i wydźwięku debaty nad jego książką nie jest wszakże odosobniona. Pojawia się wielokrotnie w tekstach różnych autorów i tak też przebieg recepcji swojego dzieła podsumował w kilku publicznych wypowiedziach sam Domosławski ${ }^{28}$.

Wrażenie nie zastąpi jednak kwerendy uczciwej, w której po prostu policzy się głosy aprobaty i dezaprobaty dotyczące poszczególnych sfer dyskusji. Warto by więc zaznaczyć poszczególne kręgi debaty: a - sposób uprawiania biografistyki przez Domosławskiego, b - polityczny wymiar KNF, c - literackość reportażu Kapuścińskiego.

Dla kontrprzykładu - Rafał Szymanowski, sympatyk KNF, wyraża pogląd zupełnie odwrotny: „W tej przestrzeni debaty, w której dyskutowano obraz PRL-u (...) głosy entuzjastyczne wobec biografii przeważyły"29.

22 R. Szymanowski, Kapuściński non-fiction ..., op. cit., s. 161-176.

23 G. Wołowiec, O Domostawskim i jego krytykach, op. cit., s. 279-287.

24 P. Zajas, Wokót Kapuściński non-fiction. Próba podsumowania i ewaluacji dyskusji, „Teksty Drugie” 2011, nr 1/2, s. 265-278.

25 U. Glensk, Siedem grzechów Domosławskiego [w:] eadem, Po Kapuścińskim, Universitas, Kraków 2012.

26 B. Nowacka, Z. Ziątek, Czytanie Kapuścińskiego po Domosławskim, Wydawnictwo Uniwersytetu Śląskiego, Katowice 2013.

27 M. Sokołowski, Reporter, agent, demistyfikator? Wokót etycznego wymiaru biografii Kapuściński non-fiction Artura Domosławskiego, „Naukowy Przegląd Dziennikarski” 2014, nr 4, s. 6-28.

28 G. Wołowiec, O Domostawskim i jego krytykach, op. cit., s. 279-280.

29 R. Szymanowski, Kapuściński non-fiction..., op. cit., s. 166. 
Być może opinia o dominującym krytycznym podejściu do KNF pasowała Grzegorzowi Wołowcowi, kierownikowi Ośrodka Studiów Literackich i Kulturowych nad Komunizmem, do tezy, która w konkluzji artykułu głosi, że:

Recepcja książki ujawniła wyraziściej niż kiedykolwiek dotąd sytuację panującą w obrębie języka rozliczeniowego z komunizmem i PRL-em (czy, szerzej jeszcze, z XX-wieczną historią Polski), jego - języka - wewnętrzną strukturę. Ukazała niebywałą siłę, a wręcz hegemonię jednej strony (...), uzależnienie od schematów interpretacyjnych i systemu wartości antykomunistycznej prawicy (...). Ataki na Domosławskiego sprawiają jednak wrażenie (...) głuchoty i ślepoty na klarownie wyłożone myśli (...), automatyzmu percepcyjnego (...). To reakcje habitualne, symptomy porządku władzy tak silnej, że niepostrzeżenie i bez reszty potrafiła zapanować nad umysłami, emocjami i ciałami sobie poddanych ${ }^{30}$.

Badacz twierdzi, że krytyczne reakcje wobec biografii były spowodowane dominującym językiem prawicy. To przykład myślenia życzeniowego i uproszczonego, niebiorącego pod uwagę retoryki KNF, sposobu budowania narracji oraz uwikłania językowego reprezentowanego przez samego autora biografii oraz jego zbyt jednoznacznej interpretacji związków Kapuścińskiego z władzą ludową, spowodowaną między innymi brakiem analizy dzieł reportażysty. Domosławski w KNF w zasadzie nie analizuje jego pisarstwa, skupiając się na jego życiu w czasach Polski Ludowej, i po części na życiu prywatnym, hojnie cytując wielu znajomych i przyjaciół Kapuścińskiego oraz ich opinie na temat jego postępowania i osobowości. W tej perspektywie umyka wykorzystywana przez Kapuścińskiego mowa ezopowa, a oświetlone zostają koneksje reportera na szczytach władzy; w gąszczu doniesień giną powody, dla których Kapuściński stał się legendą, a dominują opisy jego słabości, kompleksów i wad; wreszcie dziennikarz jawi się głównie jako prowincjusz żądny sławy, a nie człowiek o wielkiej pasji. Nie zgadzam się jednak z twierdzeniem Nowackiej i Ziątka, że głównym celem biografii powinno być kontemplowanie twórczości i odnajdywanie w niej odpowiedzi na pytania dotyczące autora ${ }^{31}$. Doceniam w KNF fakt, że Domosławski wychodzi poza te wąskie ramy i próbuje opisać zawiłe życie człowieka w kontekście burzliwej epoki, nie omijając tematów niewygodnych. Niestety, projekt demitologizacji niejednokrotnie uległ standardom prasy sensacyjnej.

Zgadzam się z Grzegorzem Wołowcem, że debata wokół KNF odsłania rytualizację języka, ale nie tylko uczestników debaty publicznej, lecz także samego Domosławskiego. Przyjrzenie się twórczości Kapuścińskiego pomaga dostrzec zarówno jego sympatię do PRL-u, lecz także jego nastawienie krytyczne do systemu (ale rzeczywiście formułowane najczęściej w duchu ruchu odnowy socjalizmu, co jako pierwszy tak dobitnie udowodnił właśnie Domosławski). Kolejna kwestia dotyczy tego, że Domosławski często dostosowuje hipotezy dotyczące życia swojego bohatera - nie zawsze wystarczająco potwierdzone - do uniwersalnej opowieści o powszechnym konformizmie inteligenta PRL czy zapomnianym obliczu minionego

30 G. Wołowiec, O Domosławskim i jego krytykach, op. cit., s. 286-287.

31 B. Nowacka, Z. Ziątek, Czytanie Kapuścińskiego po Domosławskim, op. cit., s. 23. 
ustroju. Tym samym używa on poniekąd Kapuścińskiego do próby stworzenia nowego języka o PRL-u. Nie jest tak, jak twierdzi Wołowiec, że Domosławski natrafił na nowe druzgocące fakty dotyczące związków autora Cesarza z reżimem, co spowodowało, że dziennikarz „Polityki”, chcąc chronić Kapuścińskiego, postanowił napisać książkę nie tyle o nim, ile o PRL-u:

W zamierzeniu miała być [biografia KNF - przyp. M.R.] wielką pochwałą Kapuścińskiego, jednak fakty, jakie wyłoniły się z bardzo szczegółowej kwerendy biograficznej, okazały się niemożliwe do pogodzenia z tym wyjściowym zamiarem. Nie mieściły się w ramach tak zamierzonej opowieści. Domosławski w obliczu alternatywy: zmistyfikować postać swojego bohatera czy się go wyrzec, przyjął trzecie rozwiązanie. Nie tyle rozlicza Kapuścińskiego, co poprzez niego - bardzo bliskiego sobie człowieka - sam się rozlicza z ciemnymi stronami wspólnej tradycji ideowej i politycznej ${ }^{32}$.

Już wcześniej opisano długoletnią współpracę Kapuścińskiego z PZPR-em, kontakty z wywiadem czy zauroczenie majakowszczyzną. Po prostu autor Goraczki latynoamerykańskiej skierował reflektor na fakt, że Kapuściński był ideowcem nie tylko w okresie stalinizmu, ale długo po nim. Stosunek Wołowca do metody Domosławskiego najdobitniej uwypukla jego podejście do „katyńskiego kłamstwa” Kapuścińskiego. Autor KNF stawia hipotezę, że Kapuściński świadomie kłamał, mówiąc, że jego ojciec uciekł z Katynia - ten rys martyrologiczny miał uchronić reportażystę przed lustracją. Zygmunt Ziątek udowadnia, że Domosławski nie ma żadnych poważnych dowodów pozwalających twierdzić, że Kapuściński świadomie kłamał o ucieczce jego ojca z Katynia. Wołowiec zarzuca jednak krytykom Domosławskiego, że nie zrozumieli oni intencji autora KNF, który chciał na tym przykładzie pokazać mechanizmy szantażu patriotycznego obecnego w polskim dyskursie publicznym. Problem polega jednak na tym: jeśli chce się za pomocą czyjegoś życiorysu opowiedzieć o sytuacji społecznej, należy w pierwszej kolejności być uczciwym w stosunku do faktów z biografii tej osoby, a nie dostosowywać je do z góry założonego pomysłu.

Kolejnym autorem entuzjastycznie nastawionym do KNF jest Rafał Szymanowski. Badacz wychodzi od wyróżnionych przez Przemysława Czaplińskiego dwóch narracji o PRL-u, które mają tę samą podstawę konstrukcyjną (dychotomia dobre społeczeństwo - zły reżim). Pierwsza to narracja emancypacyjna, tworzona przez obóz Solidarności; w jej perspektywie społeczeństwo wobec reżimu było krytyczne, świadome swojego ucisku, czekało na odpowiedni moment do buntu. Druga narracja nazywa się izolacyjną. To opowieść o Polakach-pragmatykach, którzy szli na kompromis z systemem, zasadniczo jednak byli systemowi przeciwni. Związani z nim pracą, owszem, ale w głębi serca uznawali jego nieprawomyślność. Szymanowski podkreśla nowatorstwo Domosławskiego i pokazuje, że dziennikarz „Polityki” stworzył nową narrację - życiorys Kapuścińskiego stanowi bowiem przykład narracji identyfikacyjnej - narracji łączącej w sobie pragmatyzm z ideowością ${ }^{33}$.

32 G. Wołowiec, O Domosławskim i jego krytykach, op. cit., s. 284.

33 R. Szymanowski, Kapuściński non-fiction ..., op. cit., s. 165. 


\section{Lewicowość inteligenta w czasach PRL-u}

Rzeczywiście, KNF to biografia pionierska pod względem wysuwania na pierwszy plan kontekstu politycznego, w który uwikłany był bohater, co bezwzględnie stanowi wielką zaletę tej książki. Problem w tym, że Domosławski nie pokazał, na czym konkretnie polegała lewicowa ideowość Kapuścińskiego; nie próbował on wystarczająco wytłumaczyć jej racjonalności i przesłanek stojącymi za taką a nie inną postawą reportażysty. Padają jedynie trzy zauważalne argumenty: po wojnie łatwo było uwierzyć w stalinowskie obietnice lepszego świata (czyli argument odwołuje się do irracjonalności traumy); reportażystą kierował koniunkturalizm (potrzeba wyjazdów zagranicznych i sławy międzynarodowej). Ostatni argument - najważniejszy - dotyczy faktu, że Kapuściński był świadkiem karygodnej działalności kapitalizmu w Trzecim Świecie, co wystarczająco zniechęciło go do krajów niekomunistycznych.

Ideowość Kapuścińskiego nie została dostatecznie opisana. A przecież w świetle paraliżu dyskursu o PRL-u trudno rozumieć, jakie mogły być pozytywne strony radzieckiego reżimu, który wykorzystywał cenzurę, nowomowę, torturował więźniów politycznych oraz atakował i zabijał protestujących robotników. Niełatwo pokazać, że można było być uczciwym człowiekiem i uważać PRL za swoją ojczyznę. Domosławski nie podjął się próby stworzenia takiego portretu.

W KNF zabrakło rozbudowanej perspektywy pozwalającej zrozumieć, dlaczego Kapuściński był zwolennikiem socjalizmu, wychodzącej poza interpretację, że był zwyczajnym konformistą. W sukurs przychodzi odważna książka PRL bez uprzedzeń pod redakcją Jakuba Majmurka i Piotra Szumlewicza. Niemal każdy artykuł zaczyna się od konstatacji, że dyskurs potransformacyjny zbudowano na patologizacji realnego socjalizmu, co związane jest między innymi z potrzebą legitymizacji nowej władzy i kapitalistycznego porządku ekonomiczno-społecznego. Stąd wielka lustracja stanowiąca przykład rytuału oczyszczającego ${ }^{34}$. Redaktorzy celnie wyróżniają trzy narracje o PRL-u ${ }^{35}$; deklarują jednocześnie, że ich publikacja to próba poszukiwania

34 Domosławski mówi, że Kapuściński bardzo obawiał się lustracji, mając na uwadze swoje związki z reżimem. W jednoznaczną polemikę z tym twierdzeniem wchodzi Jerzy Nowak w swojej książce: „Po śmierci Ryśka pojawily się przecieki z IPN o jego kontaktach z wywiadem, pisane w znanym, krzywdzącym żargonie o rzekomej «agenturalności». Niektórzy twierdzili, że ostatnie lata żył jakoby w strachu przed ich ujawnieniem. Nieraz rozmawiałem z nim na temat różnych przejawów lustracyjnej histerii. Jako historyk z wykształcenia był krytyczny wobec działań IPN, polegających na dosłownym traktowaniu dokumentów bezpieki i wywiadu jako swego rodzaju świętości. Odczuwałem u niego czasem cień niepokoju o to, jak sam zostanie uderzony, bo uważał, że wszyscy, którzy coś robili lub mieli kontakty ze światem zewnętrznym w czasach PRL byli przedmiotem działań wywiadu, często bez ich wiedzy. Istotne jest to, co robili, zwłaszcza, czy nie donosili, a nie to, czy odbywali rozmowy ze służbami specjalnymi. Te ostatnie traktował zresztą jako normalną, choć nie najlepszą część ułomnego, ale istniejącego państwa polskiego", zob. J.M. Nowak, Dyplomata ..., op. cit., s. 201.

35 J. Majmurek. P. Szumlewicz, Fakty i mity o PRL-u [w:] J. Majmurek. P. Szumlewicz (red.), PRL bez uprzedzeń, Instytut Wydawniczy „Książka i Prasa”, Warszawa 2010, s. 8-11. 
nowego języka o minionym systemie. Pierwszą opisaną przez nich narrację tworzy postsolidarnościowa prawica skupiona na narodowo-religijnej retoryce - według niej PRL to czas sowieckiej okupacji i walki z Kościołem katolickim. Fundament tej wizji stanowi przeciwstawienie uciskanego społeczeństwa i brutalnego reżimu. Autorzy polemizują z tym wyobrażeniem: „W rzeczywistości protesty pracownicze pojawiały się nie z przyczyn moralnych czy religijnych, a głównie ekonomicznych i nie w imię wyzwolenia ojczyzny, lecz wyższych płac i większej partycypacji robotników w zarządzaniu przedsiębiorstwami państwowymi" ${ }^{36}$. Druga narracja wyraża się w sentymentalnej tęsknocie - bliska jest zwolennikom idei socjalistycznych, ale też beneficjentom byłego systemu. Służy głównie obronie osób zaangażowanych w budowę PRL-u. Tymczasem redaktorzy zastrzegają, że ,pod wieloma względami Polska Ludowa była mniej egalitarna niż niektóre kraje socjalistyczne" ${ }^{37}$, przypominają o korupcji, przemocy i wzroście nierówności społecznych, które rozpoczęły się w epoce Gierka. Trzecia narracja, oparta na postmodernistycznej estetyce pastiszu i nostalgii, charakterystyczna jest dla obrońców neoliberalnego indywidualizmu, polega na demonizowaniu i wykpiwaniu PRL-u.

Wszyscy autorzy książki PRL bez uprzedzeń zastrzegają, że potępiają zbrodniczy charakter autorytaryzmu, ale chcą wyjść poza jednowymiarowe postrzeganie tego systemu. Tomasz Ciborowski i Grzegorz Konat zwracają więc uwagę na ekonomiczny aspekt PRL-u ${ }^{38}$. Pozytywnie wartościują reformę rolną, która doprowadziła do podziału wielkich parceli i przekazania części gruntów mniej zasobnym chłopom, skutkiem czego była poprawa jakości życia dominującej ówcześnie ludności rolniczej. Do sukcesów PRL-u zaliczają: industrializację (w 1946 ludność wiejska wynosiła 70\% populacji, a w 1990 - 38,8\%), elektryfikację (2\% zelektryfikowanych gospodarstw w 1945 roku, w 1971 roku - 93\%), wzrost technologiczny (wzrost liczby ciągników, zwiększona o 4,4 razy produkcja rolnicza, zwiększona produkcja żywca rzeźnego i mleka), likwidacja bezrobocia ${ }^{39}$ oraz powszechne ubezpieczenie (szczególnie biorąc pod uwagę sześćdziesięcioprocentowy przyrost liczby ludności

36 Ibidem, s. 9.

37 Ibidem, s. 10.

38 T. Ciborowski, G. Konat, Między II i III RP. Gospodarka Polski Ludowej [w:] J. Majmurek, P. Szumlewicz (red.), PRL bez uprzedzeń, op. cit.

39 Bardzo ciekawą propozycją nowej narracji o pracy w PRL-u jest książka Katarzyny Dudy Kiedyś tu było życie, teraz jest tylko bieda. O ofiarach polskiej transformacji (Instytut Wydawniczy „Książka i Prasa”, Warszawa 2019), zadydekowana Leszkowi Balcerowiczowi. Reporterka i doktorantka Kolegium Ekonomiczno-Społecznego SGH w swojej książce opisuje losy klasy robotniczej PRL-u i jej zmagań z bezrobociem bądź nowymi warunkami pracy po roku 1989. Jako badaczka w latach 20152018 brała udział w projektach dotyczących warunków zatrudniania ochroniarzy i osób sprzątających w Polsce. Okazało się, że większość osób, które badała, w PRL-u była beneficjentami systemu PRL, po transformacji znalazła się w trudnej sytuacji materialnej (które gwarantuje praca na warunkach outsourcingu). Większość jej rozmówców z sentymentem opowiada o PRL-u, wspominając gwarancję zatrudnienia i bezpieczeństwo finansowe. Narracja ofiar transformacji często przegrywa z narracją postsolidarnościową, nawet rzadko z nią współistnieje. 
po wojnie), całkowita eliminacja głodu u progu lat pięćdziesiątych i niedożywienia w latach sześćdziesiątych, ujednolicenie warunków bytu robotników i pracowników umysłowych (,Obie grupy dysponowały takimi samymi mieszkaniami, podobnym umeblowaniem i wyposażeniem. Ujednoliceniu uległ również sposób wyżywienia i ubierania się ${ }^{" 40}$ ), ułatwienie awansu społecznego, wzrost ośrodków zdrowia i rozwinięcie sieci bibliotek, powszechna i bezpłatna edukacja, gwałtowny wzrost budowy i powierzchni mieszkań (5,85 mln mieszkań w 1950 roku, 10,87 mln w 1988 roku), likwidacja analfabetyzmu (w 1931 u wśród osób powyżej 10. roku życia było 23\% analfabetów). Autorzy krytykują następujące ekonomiczne przejawy PRL-u: prymat polityki nad gospodarką, nieefektywność zarządzania gospodarką centralnie planowaną, zależność od ZSRR (co powodowało produkcyjne skupienie na przemyśle ciężkim). Ciborowski i Kornat podsumowują swój artykuł twierdzeniem, że gospodarka socjalistyczna może być reformowalna, wbrew dominującemu dyskursowi, o czym pisał nawet klasyk druzgocącej krytyki realnego socjalizmu - János Kornai w słynnej książce Niedobór w gospodarce.

Realny socjalizm, szczególnie biorąc pod uwagę kontekst wojennych zniszczeń, osiągnął również duże sukcesy. W politycznej biografii Domosławskiego zabrakło miejsca na poważną opowieść o PRL-u bez uprzedzeń. Dziennikarz „Polityki” bowiem, kreśląc portret Kapuścińskiego, skupia się przede wszystkim na historii robienia kariery w PRL-u i perypetiach dziennikarstwa, a historia ówczesnej prasy jest przede wszystkim opowieścią o cenzurze. W tej perspektywie bardzo trudno zrozumieć, na czym miałaby polegać pozytywna lewicowa ideowość reportażysty. Niewątpliwie KNF jest próbą tworzenia nowej, sprawiedliwszej narracji o PRL-u, ale próbą wciąż zakorzenioną w narracjach starych.

\section{Bibliografia}

Domosławski A., Kapuściński non-fiction, Wydawnictwo Świat Książki, Warszawa 2010.

Duda K., Kiedyś tu było życie, teraz jest tylko bieda. O ofiarach polskiej transformacji, Instytut Wydawniczy „Książka i Prasa”, Warszawa 2019.

Glensk U., Siedem grzechów Domosławskiego [w:] eadem, Po Kapuścińskim, Universitas, Kraków 2012.

Kowalska A., Kapuściński z PRL-u [w:] M. Hopfinger, Z. Ziątek, T. Żukowski (red.), Literatura bez fikcji. Między sztuka a codziennościa. W stronę nowej syntezy (3), Wydawnictwo IBL PAN, Warszawa 2018.

Kowalska A., Wokół dyskursu o PRL [w:] M. Hopfinger, Z. Ziątek, T. Żukowski (red.), Debaty po roku 1989. Literatura w procesach komunikacji. W stronę nowej syntezy (2), Wydawnictwo IBL PAN, Warszawa 2017.

Majmurek J., Szumlewicz P. (red.), PRL bez uprzedzeń, Instytut Wydawniczy „Książka i Prasa", Warszawa 2010.

40 T. Ciborowski, G. Konat, Między II i III RP..., op. cit., s. 35. 
Nowacka B., Ziątek Z., Czytanie Kapuścińskiego po Domosławskim, Wydawnictwo Uniwersytetu Śląskiego, Katowice 2013.

Nowacka B., Ziątek Z., Ryszard Kapuściński. Biografia pisarza, Wydawnictwo Znak, Kraków 2008.

Nowak J.M., Dyplomata. Na salonach i w politycznej kuchni, Bellona, Warszawa 2014.

Sokołowski M., Reporter, agent, demistyfikator? Wokót etycznego wymiaru biografii Kapuściński non-fiction Artura Domosławskiego, „Naukowy Przegląd Dziennikarski” 2014, nr 4, s. 6-28.

Stachowski A., Spór o Kapuścińskiego, Wydział Dziennikarstwa i Nauk Politycznych, Warszawa 2015.

Szymanowski R., Kapuściński non-fiction - próba analizy debaty publicznej, „Refleksje. Pismo Naukowe Studentów i Doktorantów WniPD UAM" 2012, nr 6, s. 161-176.

Wołowiec G., O Domosławskim i jego krytykach, „Teksty Drugie” 2011, nr 1/2, s. 279-287.

Zajas P., Wokół Kapuściński non-fiction. Próba podsumowania i ewaluacji dyskusji, „Teksty Drugie" 2011, nr 1/2, s. 265-278.

Ziątek Z., Reportaż - fotografia - nowe kryteria wiarygodności [w:] M. Hopfinger, Z. Ziątek, T. Żukowski (red.), Między sztuka a codziennościa. W stronę nowej syntezy (1), Wydawnictwo IBL PAN, Warszawa 2016. 